\title{
Eksistensi Pesantren Dalam Pembentukan Kepribadian Santri
}

\author{
Wiwin Fitriyah, Abd Hamid Wahid, Chusnul Muali \\ wiwinwin505@gmail.com \\ Abdhamidwahid@unuja.ac.id \\ yayahdaddy@gmail.com \\ Universitas Nurul Jadid Probolinggo
}

\begin{abstract}
Abstrak: Pesantren education essentially grows and develops based on religious motivation. The purpose is to streamline broadcasting efforts (da'wah) and practice of Islamic teaching. In its implementation, it undertook the processn of fostering knowledge, attitudes and skills thatbconcern the religious aspect. So the formation of a virtuous man (al akhlaqul karimah)is in line with a consistent religious practice or istiqomah. Therefore, pondok pesantren has to print the true human expert in the field of religion (tafaqquh fiddin, transfer knowledge to society and create good person. From there embedded the formation of good morality is the power of the soul from within that encourages people to do good and prevent bad deeds, enjoin the ma'ruf and prevent the evil. From here the behavior of good behavior (akhlaq al-karimah) which will become the character of his personality. Related to the formationof personality, there is the problem of students who become measurement of success or not about the coaching personality of santri.
\end{abstract}

Keyword: Pesantren Education, Personality of Santri.

\section{Pendahuluan}

Salah satu lembaga pendidikan di Indonesia yang mempunyai kekhasan tersendiri dan berbeda dengan lembaga pendidikan yang lainnya adalah pesantren. Institusi ini lahir, tumbuh, dan berkembang telah lama. Bahkan, semenjak belum dikenalnya lembaga pendidikan lainnya di Indonesia, pesantren telah hadir lebih awal. Itu sebabnya, pesantren pada umumnya dipandang sebagai lembaga pendidikan asli (indigenous) Indonesia. ${ }^{1}$

Hal ini senada dengan apa yang ditegaskan oleh Malik Fajar. Ia menegaskan bahwa, dalam sejarah pertumbuhan dan perkembangan pendidikan Islam di Indonesia tidak dipungkiri bahwa pesantren telah menjadi semacam local genius institution. ${ }^{2}$

Pesantren adalah salah satu asal mula pendidikan Islam tertua di Indonesia. Ia memiliki hubungan berdasarkan jabatan simbiotik dengan ajaran Islam. Yaitu, dari satu sisi keberadaan

${ }^{1}$ Azyumardi Azra, Pendidikan Islam: Tradisi dan Modernisasi di Tengab Tantangan Milenium III (Jakarta: Logos Wacana Ilmu 2000).32ww

${ }^{2}$ Fajar, M. Visi Pembaruan Pendidikan Islam (Jakarta: Lembaga Pengembangan Pendidikan dan Penyusunan Naskah Indonesia 1998). 
pesantren diwarnai oleh berbagai macam gambar dan hubungan ajaran Islam yang diikuti oleh para pendiri (pengasuh) yang mengasuhnya; sedangkan pada sisi lain, ia menjadi jembatan utama bagi proses penghayatan dan penerusan ajaran Islam kepada masyarakat. Melalui pesantrenlah agama Islam menjadi membumi dan mewarnai seluruh aspek kehidupan masyarakat: sosial, keagamaan, hukum, politik, pendidikan, lingkungan, dan lain sebagainya.

Dari sejak didirikannya pada abad ke-16 M. Hingga saat ini, pesantren tetap terus memainkan perannya yang semakin besar dan semakin luas dalam kehidupan masyarakat sosial yang menganut agama Islam. Melalui adat kebiasaannya yang unik dan berdasar pada nilai religiusitas ajaran Islam, serta kiprah pada lulusannya yang tampil sebagai tokoh nasional yang karismatik, pesantren semakin dihormati dan diperhitungkan, dan karenanya ia telah diintegrasikan kedalam sistem pendidikan nasional, sebagaimana diatur dalam undang-undang Nomor 20 Tahun 2003 tentang Sistem Pendidikan Nasioal (Sisdiknas). ${ }^{3}$

Pesantren menjadi salah satu rahim yang menetaskan para pejuang yang selain militan, juga bertanggung jawab penuh terhadap tugas serta lingkungannya. Bertanggung jawab secara vertikal maupun horisontal dalam melahirkan serta membesarkan Indonesia. Hal itu karena pesantren adalah kawah candradimuka bagi para santri sebelum benar-benar diterjunkan ke masyarakat. Hal itu tampak pada masyarakat yang hakiki pada masa pergolakan, ataupun yang bukan masyarakat, jika dihubungkan masa-masa sekarang. Para santri yang alumni pesantren yang benar-benar belajar saat masa karantina, umumnya memang akan berkarakter dengan penih gairah, bersifat keagamaan serta sekaligus bertanggung jawab terhadap kewajibannya. Pesantren yang dimaksud di sini tentu saja pesantren salaf yang berhaluan Ahl al-Sunnah Wa al-Jama'ah, bukan pesantren yang pseudo ahli Sunah, apalagi pesantren berhaluan mendasar yang bisa ditemukan dengan mudah pada masa sekarang. Munculnya bermacam-macam arah pesantren yang aneh dan menyimpang pada masa modern sekarang agaknya turut memupuk sikap kurang percaya masyarakat atas pesantren. Karena itulah, kiranya perlu diklasifikasi kembali ragam pesantren dan diurai benang kusut penyebab timbulnya sikap skeptis masyarakat Indonesia terhadap pesantren.

\section{Pondok Pesantren dalam berbagai kalangan}

Pondok pesantren berasal dari kata pondok dan pesantren. Pondok berasal dari kata Arab "fundug " yang bermakna tempat penginapan atau asrama. Sedangkan kata pesantren berasal dari kata santri yang dengan berawalan "pe" dan berakhiran ,an" berarti tempat tinggal para santri atau boarding school. Keduanya mempunyai hubungan yang sama, yakni menuju pada suatu perumahan untuk kediaman (tempat tinggal) dan belajar santri (peserta didik).

\footnotetext{
${ }^{3}$ Abuddin Nata, Sejarah Sosial Intelektual Islam (Jakarta: Rajawali Pers, 2012).
} 
Pesantren mempunyai fungsi penting sebagai pusat pendidikan dan pemberitahuan agama Islam. Maulana Malik Ibrahim mendidik dan membina sejumlah santri yang ditampung dan tinggal bersama dalam rumahnya di Gresik. ${ }^{4}$

Pondok pesantren adalah sebuah sekolah yang terletak pada lingkungan masyarakat Indonesia dengan beberapa model pembinaan yang sarat akan pendidikan nilai, baik nilai itu agama maupun nilai-nilai luhur bangsa. Sehingga pesantren menjadi lembaga yang sangat efektif dalam pengembangan pendidikan karakter (akhlak) peserta didik. ${ }^{5}$

Dalam penegasan lain pondok pesantren merupakan lembaga multi-fungsional yang tidak hanya berkutat pada perkembangan pendidikan Islam, namun juga sangat berperan bagi kemajuan pembangunan lingkungan sekitar. ${ }^{6}$ Pondok pesantren merupakan dua istilah yang menunjukkan kepada pengertian yang sama. Suku jawa biasanya menggunakan istilah pondok/pesantren dan sering menyebutnya sebagai pondok pesantren. Daerah Sumatra Barat menyebut pondok pesantren dengan Surau, Aceh denngan Meunasah, Rangkang, dan Dayah. ${ }^{7}$

Secara historis, pesantren atau pondok tak lain merupakan perwujudan sistem pendidikan nasional. Selain identik dengan keislaman sebagai ajaran mayoritas bangsa, pesantren juga mengandung makna keindonesiaan (Indigeneous). Sebab, lembaga serupa pesantren sebenarnya sudah ada sejak masa kekuasaan Hindu-Buddha. Sehingga Islam tinggal meneruskan dan mengembangkan Islam dengan model-model yang sudah ada. Tentunya ini tidak lantas mengecilkan peranan Islam dalam memplopori pendidikan di Nusantra ini, sejak masa para penjajahan. $^{8}$

Pondok pesantren merupakan acuan Pendidikan Agama Islam yang berkembang dan diakui oleh masyarakat sekitar, dengan mekanisme asrama (kampus) dimana para peserta didik dapat mengabulkan pendidikan agama melalui teknik pengajian atau institusi yang semuanya berada dibawah independensi dari administrator atau beberapa kiai dengan ciri-ciri khas yang bersifat independen serta kharismatik dalam segala hal. Pengertian pesantren yang populer pada saat inin yaitu bahwa pesantren atau pondok pesantren adalah suatu lembaga pendidikan Islam Indonesia yang bertujuan untuk mendalami ilmu agama Islam, dan mengamalkannya sebagai pedoman

\footnotetext{
${ }^{4}$ Ahmad Syamsu Rizal, "Pesantren Corak Edukasi Dalam Sistem Pendidikan Pesantren, Dari Pola Tradisi Ke Pola Modern", dalam Jurnal Urnal Pendidikan Agama Islam -Ta'lim, Vol. 9, No. 2 (2011), 97.

${ }^{5}$ Fifi Nofiaturrahmah, "Metode Pendidikan Karakter Di Pesantren", dalam Jurnal Pendidikan Agama Islam, Vol. XI, No. 2 Juni-Desember (2014), 202.

${ }^{6}$ Ziemek, Manfred, Pesantren Dalam Perubahan Sosial, (Jakarta: P3M, 1986).

${ }^{7}$ Dauly Haidar, Historisitas dan Eksistensi Pesantren, Sekolab dan Madrasah. (Yogyakarta: Tiara Wacana, 2001)

${ }^{8}$ Ahmad Muhakamurrohman, "Pesantren: Santri, Kiai, Dan Tradisi", dalam Jurnal Ibda' Kebudayaan Islam, Vol. 12, No. 2 Juli-Desember (2014), 112.
} 
hidup seharian, atau disebut tafaqquh fi addin, dengan menekankan pentingnya moral dalam hidup bermasyarakat. ${ }^{9}$

Oleh sebab itu, sebagian orang tua, pendidik, dan anggota masyarakat Indonesia banyak mengeluhkan dan mewaspadai terhadap pendidikan Agama yang kurang mendapat perhatian yang cukup dari pemerintah. Meskipun secara umum, tujuan pemerintah Indonesia adalah untuk menciptakan pembangunan seimbang antara unsur material dan unsur spiritual, tetapi tampaknya pemerintah lebih memberikan perhatian yang besar terhadap tujuan yang bersifat materil. Implikasinya, ada usahausaha untuk mengembalikan nilai-nilai tradisional terutama dalam mempertimbangkan kembali peranan pendidikan tradisional Islam, yaitu pesantren, yang kaya dengan pendidikanmoral dan spiritual. Sama sekali Tidaklah heran jika Muslih Usa menyatakan bahwa ; sangatlah aneh ketika keseluruhan masyarakat Indonesia adalah Muslim, akan tetapi apabila pendidikan Islam tidak diberikan kesempatan untuk bersaing dalam pembangunan masyarakat yang besar. ${ }^{10}$

Mengacu pada pendapat beberapa para ahli di atas, pesantren ialah lembaga pendidikan Islam murni Indonesia yang memiliki banyak panggila seperti meunasah, surau, dayah, dan rangkang, yang didalamnya terdapat asrama sebagai tempat tinggal santri dan sekalligus dipergunakan untuk proses belajar mengajar.

Sudjoko Prasodjo menyatakan bahwa pesantren ialah sekolah dan pengajaran yang mempunyai kaitan dengan agama Islam, galibnya dengan cara nonklasikal, dimana seorang kiai atau pengasuh dan para santri biasanya tinggal di asrama (kamar) dalam pesantren tersebut. Sedangkan Menurut dasar kata dari pesantren berasal dari kata santri yang memiliki imbuhan awalan pe dan akhiran an yang disebut tempat tinggal. Dengan begitu, pondok pesantren adalah tempat tinggal para santri. ${ }^{11}$

Keberadaan pesantren terus tumbuh dan berkembang dengan cukup pesat dalam masyarakat tersebar ke pelosok-pelosok tanah air. Progres dan evolusi pesantren ini disuport oleh beberapa aspek sosio-cultural-keagamaan yang kontributif sehingga eksistensi pesantren ini semakin tangguh berakar dalam kebudayaan dan kehidupan masyarakat Indonesia. Beberapa aspek yang menjadi penguat keberadaan pesantren diantaranya adalah : (1) Agama Islam sudah bertambah menyebar di pelosok-pelosok tanah air, oleh karena itu banyak pesantren dan masjid yang didirikan oleh umat Islam untuk dijadikan sarana pembinaan dan pengembangan syi'ar Islam, (2) Kedudukan dan kharisma para kiai dan ulama (yang memperoleh penghormatan, penghargaan,

\footnotetext{
${ }^{9}$ Muzayyin Arifin, Kapita Selekta Pendidikan Islam (Jakarta: Bumi Aksara, 2003).

${ }^{10}$ Hasan Baharun, Pengembangan Kurikulum : Teori Dan Praktik (Yogyakarta: Pustaka Nurja, 2017).

11 Sudjoko Prasodjo, Sejarah Pertumbuban dan Perkembangan Lembaga-lembaga Pendidikan Islam di Indonesia (Jakarta: Grasindo 2001).y
} 
dan perhatian dari para Sultan pada masa itu) sangat berperan dalam pertumbuhan dan perkembangan pesantren. Sebagai contoh, pesantren Tegal sari di Jawa Timur didirikan pada tahun 1792, (3) Siasat pemerintah kolonial Belanda yang terus memecah belah antara para penguasa dan ulama telah mempertinggi semangat jihad umat Islam untuk melawan Belanda. Menghindari hal ini, para kiai hijrah ke tempat-tempat yang jauh dari kota dan mendirikan pesantrensebagai basis pemusatan kekauatan mereka di desa-desa, (4) Kebutuhan umat Islam yang semakin mendesak akan sarana pendidikan yang Islami, karena sekolah-sekolah Islalm Belanda secara terbatas hanya menerima murid-murid dari kelas social tertentu, dan (5)Semakin lancarnya antara Indonesia dan Tanah suci Mekkah yang memungkinkan para pemuda Islam Indonesia untuk belajar ke Mekkah yang merupakan pusat studi Islam. Sepulang dari tanah suci (Mekkah), banyak sebagian besar dari mereka yang mendirikan pesantren untuk mengajarkan dan mengembangkan agama Islam di daerahnya masing-masing. ${ }^{12}$

Para ulama yang tidak mau bekerjasama dengan pihak penjajah, sejak awal menghindari tradisi dan ajaran Islam dari pengaruh budaya barat, terutama yang dibawa oleh penjajah. Semua bentuk kebudayaan barat yang dipandang sebagai sesuatu yang harus dijauhi oleh umat Islam.

Pesantren adalah salah satu institusi yang unik dengan ciri-ciri khas yang sangat kuat dan lekat. Peran yang diambil adalah upaya-upaya pencerdasan bangsa yang telah turun temurun tanpa henti. Dengan garis besar pesantren adalah salah satu lembaga yang memberikan pendidikan pada masa penjajahan, pada masa perjuangan melawan penjajah dan menjadi pusat studi yang tetap bertahan sampai saat ini. Ada banyak pesantren di Indonesia, baik salaf ataupun nonsalaf yang telah memberikan kontribusi bagi proses pencerdasan masyarakat Indonesia. Dua di antaranya adalah Pesantren Langitan, Tuban dan Pesantren Ihyaul Ulum, Gilang, Lamongan. ${ }^{13}$

Pondok pesantren muncul menjadi sebuah institusi yang memiliki berbagai kelengkapan fasilitas untuk membangun potensi-potensi santri, tidak harus dalam segi akhlak-nilai, intelektual dan spiritual, tetapi juga atribut fisik dan material. Dengan tetap mempertahankan ciri khas bandongan dan sorogan, melalui kajian kitab-kitab kuning (kitab klasik yang berbahasa arab), pesantren juga mengadopsi sistem klasikal formal. Seperti yang terdapat pada madrasah atau sekolah umum, tetapi dengan mempertahankan keaslian materi kurikulum yang sudah ada. Pesantren mengadopsi sistem sekolah sekaligus kurikulum yang ditawarkan. Pesantren akan dapat berperan efektif bila ada upaya meningkatkan peran sertanya dlam tatanan kehidupan

12 Marwan Saridjo, Sejarah Pondok Pesantren di Indonesia (Jakarta: Darmabhakti, 1982).

13 Syaiful Mustofa, "Pendidikan Islam Dalam Perspektif Pesantren (Antara Idealita DAN Realita Di Era Modern)", dalam Jurnal El-Hik.mah Fakultas Tarbiyah UIN Maliki Malang. 
masyarakat modern. Peningkatan peran pesantren tersebut akan mempunyai makna yang sangat besar dalam mewujudkan tatanan ke Islaman menjadi rahmat bagi seluruh alam di Indonesia. ${ }^{14}$

Ada beberapa elemen pesantren yang membedakan dengan lembaga pendidikan lain, yaitu: (1) Pondok (tempat bermukim para santri) Merupakan sebuah asrama atau tempat tinggal pendidikan islam tradisional di mana para peserta didiknya bermukim atau tinggal bersama dan mencari ilmu di bawah pengarahan seorang (atau lebih) guru yang lebih dikenal dengan sebutan kyai (pengasuh), (2) Santri (peseta didik) Santri merupakan elemen penting dalam suatu lembaga pesantren. Menurut adat pesantren, terdapat 2 macam santri (peserta didik) : a) Santri mukim yaitu peserta didik yang berasal dari daerah yang jauh dan menetap dalam kelompok pesantren. b) Santri kalong yaitu peserta didik yang berasal dari desa-desa disekeliling pesantren, yang biasanya tidak menetap dalam pesantren. Untuk mengikuti pelajarannya di pesantren, mereka bolak-balik(nglajo) dari rumah sendiri. Dalam menjalani suasanakehidupan baru di pondok pesantren, biasanya mereka mengurus diri sendiri keperluan sehari-hari dan mereka mendapat fasilitas yang sama antara santri yang satu dengan lainnya. Santri diharuskan dan diwajibkan mengikuti semua aturan yang telah ditetapkan di dalam pondok pesantren tersebut dan jika ada pelanggaran akan dikenakan sanksi sesuai dengan bentuk pelanggaran yang dilakukan oleh santri atau peserta didik, (3) Masjid (pusat kegiatan pesantren dan sarana ibadah) tingkatan masjid sebagai sumber pendidikan dalam adat pesantren ialah perwujudan dari universalitas metode pendidikan Islam tradisional. Atau kontinuitas aspek pendidikan Islam yang bertaut di masjid dari masjid Quba yang didirikan di Madinah pada zaman Nabi Muhammad SAW tetap terbersit dalam sistem pondok pesantren.. Di Jawa biasanya seorang Kyai itu yang menyebarluaskan atau mengembangkan sebuah pondok pesantren yaitu dengan cara pertama-tama dengan mendirikan masjid di dekat rumahnya. Langkah ini pun biasanya diambil atas perintah Kyainya yang telah menilai bahwa ia smampu memimpin sebuah pesantren. Selanjutnya Kyai tersebut akan mengajar dan membina murid-muridnya (para santri) di masjid, sehingga masjid merupakan elemen yang sangat penting dari pondok pesantren. Merupakan komponen yang tidak dapat dipisahkan dengan pesantren dan ditanggap sebagai tempat yang paling tepat untuk mendidik dan membina para santri (peserta didik), terutama dalam manifestasi sholat lima waktu, sholat jum'at dan khutbah, dan pengajaran kitab-kitab islam klasik. (4) Kiai (tokoh atau sebutan seseorang melebihi dari sisi agama dan pamor yang dimiliki) Kyai tidaklah berasal dari kata bahasa Arab, melainkan dari bahasa Jawa. Kata Kyai mempunyai makna yang keramat, dituahkan, dan agung. Selain gelar Kyai diberikan kepada seorang laki-laki yang lanjut usia, dihormati, dan arif di Jawa. Gelar Kyai juga diberikan untuk benda-benda yang keramat dan dituahkan, seperti keris dan tombak. Dalam

14 Muhammad Heriyudanta, "Modernisasi Pendidikan Pesantren Perspektif Azyumardi Azra", dalam Jurnal Mudarrisa Kajian Pendidikan Islam, Vol. 8, No. 1 Juni (2016), 150. 
beberapa hal, kepemimpinan kyai dalam pesantren akan ditentukan olehlatar belakang kepribadian kyai, yaitu meliputi pola pikir, sikap, jiwa, serta orientasi tertentu untuk memimpin. Hal ini menggambarkan begitu besarnya peran Kyai dalam menentukan keberhasilan pesantren yang diasuhnya. Merupakan elemen yang paling esensial dari suatu pesantren.Ia seringkali bahkan merupakan pendirinya. Sudah seharusnya bahwa perkembangan suatu pesantren semata-mata bergantung kepada kemampuan pribadi kyainya. Dengan kaitan yang sangat kuat dengan adat pesantren, gelar kyai biasanya dipakai untuk merujuk para ulama dari kelompok Islam tradisional.

Kepemimpinan dalam organisasi memiliki peran yang sangat besar dalam membangun hubungan antar individu dan pembentuk nilai organisasi yang dijadikan sebagai pondasi dasar bagi pencapaian tujuan organisasi. Pengaruh kepemimpinan terhadap efektivitas organisasi dapat dilihat sebagai efek kepemimpinan langsung dan tidak langsung ${ }^{15}$, (5) Kitab kuning (sebagai referensi pokok dalam kajian keislaman) Pada zaman dahulu, pengajaran dan pembinaan kitabkitab Islam klasik, terutama karangan-karangan ulama yang menganut faham syafi" iyah, merupakan satu satunya pengajaran dan pembinaan formal yang diberikan dalam lingkungan pesantren. Tintensi utama pengajaran ini yaitu untuk mengajar dan membina calon-calon ulama. Keseluruhan kitab-kitab yang diajarkan di pondok pesantren yaitu: saraf dan nahwu, usul fiqh, fiqh, tasawuf, hadist, tafsir, tauhid, cabang-cabang lain separti sejarah dan balaghah. Kitab-kitab Islam di kalangan pondok pesantren lebih dikenal dengan sebutan kitab kuning. Alasan penyebutan istilah ini mungkin untuk membatasi tahun karangan atau karena warna kertas dari kitab tersebut berwarna kuning.

Penyebutan kitab-kitab Islam di dunia pondok pesantren lebih dikenal dengan sebutan "kitab kuning", tetapi asal mula istilah ini belum diketahui secara pasti. Mungkin penyebutan istilah tersebut untuk membatasi tahun karangan atau karena disebabkan warna kertas dari kitab tersebut berwarna kuning, tetapi tindakan ini kurang tepat sebab pada saat ini kitab-kitab Islam klasik sudah banyak dicetak dengan kertas putih.

Dari beberapa definisi diatas, jelaslah bahwa secara etimologi, pondok pesantren merupakan satu lembaga kuno sebagai tempat pengajaran berbagai ilmu pengetahuan agama. Olehkarena itu wajar apabila ada sisi kesamaan (secara bahasa) antara pondok pesantren yang ada dalam sejarah Hindu dengan pondok pesantren yang muncul belakangan. Antara keduanya memiliki kesamaan prinsip pengajaran ilmu agama yang dilakukan dalam asrama. ${ }^{16}$

\section{Pembaharuan Sistem Pendidikan Pondok Pesantren}

\footnotetext{
${ }^{15}$ Hasan Baharun, "Peningkatan Kompetensi Guru Melalui Kepemimpinan Kepala Madrasab", dalam Jurnal AtTajdid: Ilmu Tarbiyah, Vol. 6, No. 1 Juli (2017), 248.

${ }^{16}$ Fauzan, Sejarah Sosial Pendidikan Islam (Jakarta: Kencana, 2008). 
Kegelisahan masyarakat mengharuskan dunia pendidikan mampu menenangkan jiwa masyarakat. Peranan pendidikan didalam perubahan kehidupan suatu komunitas memang sangat menentukan. Pendidikan rakyat telah menunjang perubahan masyarakat tradisional menjadi masyarakat industri di Eropa. Pendidikan memberikan kemampuan kepada suatu komunitas untuk melihat kemungkinan-kemungkinan yang terbuka dimasa depan. Masyarakat masa depan adalah masyarakat yang berbasis ilmu pengetahuan. Artinya, apabila kekuatan ilmu pengetahuan tidak digunakan sebagaimana mestinya maka suatu komunitas akan terjepit di antara kekuatankekuatan yang ada sehingga mengakibatkan kehancuran komunikasi. Itu sebabnya mengapa pendidikan merupakan modal utama dalam menghadapi masa depan. ${ }^{17}$

Pesantren bebas menerapkan 24 jam operasional belajar. Pada umumnya, pesantren tradisional melakukan proses transformasi keilmuan melalui one-way-communication. Dengan cara ini kyai atau ustadz menjadi sumber pembelajaran utama. Akan tetapi, sistem sekolah yang ada di dalam pesantren hampir tidak ada bedanya dengan sekolah-sekolah di luar lingkungan pesantren, yaitu proses pembelajaran yang lebih variatif dan dinamis. ${ }^{18}$

Pada mulanya, pendidikan pesantren bertujuan untuk mencetak ustadz, kyai muda, dan ulama: mereka yang memiliki ilmu agama mumpuni. Namun dalam perkembangannya pesantren melakukan adaptasi dengan skema pendidikan modern dengan dua kurikulum: agama dan non agama, tujuannya mencetak ilmuan agamis atau kyai intelektual. Apabila dibuat system klasikal mungkin ini akan menjadi Madrasah diniah. Pesantren yang telah membuka sekolah atau madrasah mengadaptasi kurikulum nasional dan tentu lebih complex system pembelajaran dan managemennya.

Menurut Mastuhu dalam Manfred intensi pendidikan pondok pesantren adalah mengembangkan dan menciptakan kepribadian muslim, yaitu kepribadian yang bertaqwa kepada Tuhan dan beriman, berakhlaq mulia, bermanfaat bagi masyarakat atau berkhidmat pada masyarakat dengan jalan menjadi sahaya atau abdi masyarkat sekaligus menjadi rasul, yaitu mampu berdiri sendiri, bebas dan teguh dalam kepribadian, menjadi pelayan masyarakat sebagaimana kepribadian Nabi Muhammad Saw (mengikuti sunnah nabi), mensyi'arkan agama atau menegakkan agama Islam dan kejayaan Umat Islam di tengah-tengah masyarakat (i₹zul Islam wal muslimin) serta mencintai ilmu dalam rangka mengembangkan kepribadian Indonesia.

Dari rumusan tujuan di atas, tampak jelas sekali bahwa pendidikan di pondok pesantren sangat menekankan pada pentingnya menghidupkan Islam ditengah-tengah kehidupan. Itu

${ }^{17}$ Hasan Baharun and Robiatul Awwaliyah, "Pendidikan Multikultural Dalam Menanggulangi Narasi Islamisme Di Indonesia", Jurnal Pendidikan Agama Islam (Journal of Islamic Education Studies), Vol. 5, No. 2 (2017), 228.

${ }^{18}$ Husmiaty Hasyim, "Transformasi Pendidikan Islam (Konteks Pendidikan Pondok Pesantren)", dalam Jurnal Ta'lim Pendidikan Islam, Vol. 13, No. 1 (2015), 62. 
artinya profesionalisme santri harus terus ditingkatkan sebagai model menegakkan Islam di tengah-tengah kehidupan yang semakin pesat dan selalu mengalami perubahan. ${ }^{19}$

Keistimewaan pesantren dalam program Pendidikan Nasional dapat diketahui dari ketentuan dan penjelasan Pasal-Pasal dalam UU No. 23 Tahun 2003 Pasal 3 yang menjelaskan bahwa pendidikan nasional berfungsi mengembangkan membangun watak dan kemampuan serta peradaban bangsa yang bermartabat dalam rangka mencerdaskan kehidupan bangsa dan Mengacu pada UU No. 20 Tahun 2003 tentang program Pendidikan Nasional, keberadaan dan posisi pesantren sebenarnya mempunyai tempat yang sangat istimewa, bertujuan untuk berkembangnya kapasitas peserta didik agar menjadi manusia yang bertakwa dan beriman kepada Tuhan Yang Maha Esa, beretika, sehat, berilmu, cakap, kreatif, mandiri, dan menjadi warga Negara yang absolut serta responsibilitas. Ketentuan ini, sudah berlaku dan menjadi tujuan yang harus diimplementasikan pondok pesantren. ${ }^{20}$

Menurut H. M. Arifin. Rumusan tujuan pondok pesantren adalah sebagai berikut : (1) Tujuan umum, Membentuk muballigh-muballigh Indonesia berjiwa Islam yang bertaqwa, mampu baik rohaniyah maupun jasmaniyah dengan mengamalkan ajaran agama Islam bagi kepentingan kebahagian hidup diri sendiri, keluarga, masyarakat dan bangsa serta Negara Indonesia. (2) Tujuan khusus, (a) Memberikan keterampilan, olah raga dan kesehatan kepada santri. (b) Memberikan pengertian keagamaan melalui praktek ajaran ilmu agama Islam. (c) Mengembangkan sikap beragama melalui praktik-praktik ibadah. (d) Mewujudkan persaudaran dalam pondok pesantren dan sekitarnya. Dan (e) Membimbing suasana hidup keagamaan dalam pondok pesantren sebaik mungkin sehingga menarik pada jiwa anak didiknya (santri).

Menurut Ahmad Syamsul Rizal Pesantren merupakan lembaga pendidikan Islam di Indonesia, dari awal keberadaannya bertujuan hendak membimbing individu-individu Muslim agar mempunyai ciri-ciri kepribadian Islami, yang tampil dalam pola fikir, pola sikap dan pola tindaknya. Oleh sebab itu, dasar pendidikannya adalah pembinaan akhlak. ${ }^{21}$

Meskipun demikian, pada pesantren-pesantren tradisional tujuan ini tidak dituangkan dengan eksplisit secara tertulis, tetapi secara implisit terekspresikan dari bahan pelajaran yang diberikan, proses dan cara pengajaran, dan norma-norma yang berlaku dalam interaksi pendidikan yang yang dikembangkannya. Hasil analisis Dhofier tentang pesantren secara sosiologis menggambarkan tujuan pendidikan dipesantren adalah tujuan pendidikan tidak semata-mata untuk memperkaya fikiran murid dengan penjelasan-penjelasan, tetapi untuk meninggikan moral,

\footnotetext{
${ }^{19}$ Nurotun Mumtahanah, "Pengembangan Sistem Pendidikan Pesantren dalam Meningkatkan Profesionalisme Santri" AL HIKMAH Jurnal Studi Keislaman, Vol. 5, No. 1 Maret (2015), 238.

20 Sri Wahyuni Tanshzil, "Model Pembinaan Pendidikan Karakter Pada Lingkungan Pondok Pesantren Dalam Membangun Kemandirian Dan Disiplin Santri", dalam Jurnal Penelitian Pendidikan, Vol. 13, No .2 Oktober (2012), 4.

${ }^{21}$ Mukromin, "Implementasi Pendidikan Karakter Di Pesantren", dalam Jurnal Al-Qalam, Vol. XII, 138.
} 
melatih dan mempertinggi semangat, menghargai nilai-nilai spiritual dan kemanusiaan, mengajarkan etika dan tingkah laku yang jujur dan bermoral, dan menyiapkan para peserta didik untuk hidup sederhana, qonaah dan bersih hati. Setiap peserta didik diajar agar menerima etika agama di atas etik-etik yang lain. intensi pendidikan pesantren tidaklah untuk mengejar kepentingan kekuasaan, uang dan keagungan duniawi, tetapi ditanamkan kepada mereka bahwa belajar yaitu semata-mata kewajiban, keharusan dan pengabdian kepada Tuhan. intensi tersebut secara langsung diarahkan pada pembinaan dan pembimbingan kepribadian para santri sendiri sebagai hamba Allah swt., yang harus berakhlakul karimah. ${ }^{22}$

Imam Suprayogo, Professor of Islamic Education, menyatakan bahwa Indonesian academic system has made a big mistake because it did not pay enough attention to the pesantren education pattern. Pesantren, he continues, is the best model of educational system. Therefore, adapting pesantren educational system will help colleges or schools create qualified students. The model of education in pesantren centers at the spirit of students and respect of teachers to enhance noble character. As a result, both of their heart and brain are strongly educated and it implies to the school outcomes. ${ }^{23}$

Pengajaran pondok pesantren lebih mengutamakan niat karena segala sesuatu harus diawali dengan niat untuk mendapatkan ilmu pengetahuan yang bermanfaat dari pada mengejar hal-hal yang bersifat material. Tujuan pondok pesantren adalah: untuk menanamkan rasa keagamaan tersebut pada semua segi kehidupan sebagai orang yang berguna bagi agama, masyarakat dan bangsa. Dan membina warga negara agar berkepribadian muslim sesuai dengan ajaran-ajaran agama Islam dan menanamkan rasa keagamaan tersebut pada semua segi kehidupan sebagai orang yang berguna bagi agama, masyarakat dan bangsa. ${ }^{24}$

Untuk mengingatkan kepada Allah SWT, para pengasuh (kiai) pondok pesantren memulai pendidikan pesantrennya dengan modal niat ikhlas untuk berdakwah menegakkan kalimat-Nya, tujuan pendidikan itu sendiri adalah menciptakan dan mengembangkan kepribadian muslim, yaitu kepribadian yang beriman dan bertakwa kepada Allah SWT, berakhlak mulia, bermanfaat bagi sesama manusia yang didukung dengan sarana prasarana sederhana dan terbatas. Berkaitan dengan jiwa kesederhanaan. sebagai pelayan masyarakat, mandiri, bebas dan teguh dalam kepribadian, mensyi'arkan agama, atau menegakkan agama Islam dan kejayaan umat Islam di

\footnotetext{
22 Nur Jamal, "Transformasi Pendidikan Pesantren Dalam Pembentukan Kepribadian Santri", dalam Jurnal Tarbiyatuna: Pendidikan Islam, Vol. 8, No. 2Agustus (2015), 171.

${ }^{23}$ Hasan Baharun, "Total Moral Quality: A New Approach for Character Education in Pesantren", dalam Jurnal Ulumuna, Vol. 21, No. 1 June (2017), 59.

${ }^{24}$ Mujamil Qomar, Pesantren Dari Transformasi Metodologi Menuju Demokrasi Institusi (Jakarta: Erlangga, 2002).
} 
tengah-tengah masyarakat ('izæul Islam wal muslimin), dan mencintai ilmu dalam rangka mengembangkan kepribadian Indonesia. ${ }^{25}$

Tujuan pesantren yaitu membentuk kepribadian, memantapkan akhlaq dan melengkapinya dengan ilmu pengetahuan. Mereka diharapkan setelah kembali ke Kampung halamannya menempuh hidupnya sebagai muslim teladan yang memantulkan sosialisasi pesantrennya serta mempromosikan pesantre, menyiarkan nilai-nilai dan gambaran kemasyarakatan Islam. ${ }^{26}$

\section{Kapasitas dan Tanggung Jawab Pesantren terhadap Kepribadian Santri}

Masuknya Islam di Nusantara mengarahkan pada tata cara peradaban baru melalui pakaian yang menutup aurat, hidup bersuci, disiplin, cara membangun keluarga, pertanian, peternakan, bahkan hingga pertumbuhan ekonomi. Fuad Suwito mengatakan Pondok pesantren memiliki peranan penting dalam hal sebagai "perwakilan perubahan" untuk membentuk pembelajaran pada santri, maupun masyarakat yang ada di sekitarnya..

Pondok pesantren sebagai lembaga pendidikan memberikan pengaruh yang sangat besar pada pengetahuan masyarakat. Pada zaman sebelum Islam, sebagian penduduk di Jawa hanya memakai pakaian ala kadarnya saja, dan hanya pada bagian tertentu, namun sejak adanya Islam mengajarkan untuk bagian taharah dan menutup aurat saat shalat menjadikan orang di Jawa terbiasa dengan pakaian yang rapat. Dari sejarah ini, dapat dipahami bahwa sesungguhnya keberadaan Islam membawa pembaharuan bagi masyarakat di sekitar. Adapun yang lebih penting lagi adalah peranan pondok pesantren dalam keterlibatan pada bangsa dan negara, yakni dengan melahirkan tokoh-tokoh penting untuk pengambil kebijakan. Dapatlah dicermati juga peranan tokoh Islam dalam Pancasila, yaitu "ketuhanan Yang Maha Esa". ${ }^{27}$

Dari sudut pandang lain, fungsi pendidikan pesantren dapat dikatakan sebagai alat pengendalian sosial (agent of social control) bagi masyarakat. Tatkala terjadi penyimpangan sosial (deviation) dalam masyarakat, khususnya penyimpangan dalam hal yang berkaitan dengan nilainilai Islam, maka fungsi pesantren sebagai alat pengendalian sosial hars dapat berjalan sebagaimana mestinya.

Penyimpangan sosial lebih dominan muncul dikalangan masyarakat perkotaan. Hal ini di ungkapkan oleh Emile Durkheim bahwa "Gejala Deviasi pada masyarakat Indonesia lebih banyak muncul di kalangan masyarakat kota besar, yang cenderung merupakan perwujudan mentalitas menerabas yang pada hakekatnya menimbulkn sikap untuk mecapai tujuan secepatnya

${ }^{25}$ Rini Setyaningsih, "Kontinuitas Pesantren Dan Madrasab Di Indonesia", dalam Jurnal At-Ta'dib, Vol. 11, No. 1 Juni (2016), 171.

${ }^{26}$ Ziemek

${ }^{27}$ Atabik, "Historisitas Dan Peran Pondok Pesantren Somalangu Di Pesisir Selatan", dalam Jurnal Ibda' Kebudayaan Islam, Vol. 1, No. 2 Juli-Desember (2014), 187. 
tanpa banyak berkorban dalam arti mengikuti langkah-langkah atau kaedah-kaedah yang telah ditentukan. Gejala seperti ini oleh Emile Durkheim dinamakan sebagai anomie”. ${ }^{28}$

Pondok pesantren mempunyai berbagai macam peran penting dalam meningkatkan kualitas sumber daya manusia. Seperti pada umumnya diketahui, pondok pesantren sebenarnya tidak hanya memberikan pengetahuan dan keterampilan teknis, tetapi yang jauh lebih penting adalah menanamkan nilai-nilai agama dan sikap.sejarah pendidikan pesantren di dasarkan atas hubungan yang berarti antara manusia dengan Allah SWT hubungan tersebut mempunyai makna jika menghasilkan keagungan dan keindahan. Ibadah yang di jalani oleh semua ustadz dan peserta didik di pondok pesantren diutamakan dalam hal mencari ilmu, mengelola pelajaran, mengembangkan kegiatan bersama santri dan masyarakat dan mengembangkan diri. ${ }^{29}$

tujuan dan karakter pondok pesantren menurut Adi Sasono, Didin Hafiduddin dkk, dan Mastuhu, itu ada tiga jenis macam yaitu: pondok pesantren sebagai institusi kemasyarakatan, institusi keagamaan/sebagai institusi penyiaran agama, dan sebagai institusi pendidikan: (1)Pondok pesantren sebagai lembaga keagamaan, Ajaran agama Islam sudah pasti diajarkan sekaligus dipraktikkan di pondok pesantren, baik sebagian maupun secara keseluruhan. (2) Pondok pesantren sebagai lembaga sosial Pengertian masalah-masalah sosial yang dimaksud oleh Pesantren pada dasarnya bukan saja terbatas pada aspek kehidupan duniawi melainkan tercakup didalamnya masalah-masalah ukhrawi, yang berupa bimbingan rohani yang menurut Sudjoko Prasodjo merupakan jasa besar pesantren terhadap masayarakat desa yakni: (a) Kegiatan tabligh kepada masyarakat yang dilakukan dalam kompleks pesantren. (b) Majelis ta'lim atau pengajian yang bersifat pendidikan kepada umum. (c)Bimbingan hikmah berupa nasehat kiayi pada orang yang datang untuk diberi amalan-amalan apa yang harus dilakukan untuk mencapai suatu hajat, nasehat-nasehat agama dan sebagainya. (3)Pondok pesantren sebagai lembaga pendidikan, Dalam memberikan pelayanan kepada santri, pondok pesantren menjanjikan sarana-sarana bagi perkembangan pribadi muslim para santri. Tumbuh dan berkembangnya pribadi muslim, para santri dipengaruhi pengalaman-pengalaman sebelum masuk pesantren, kawan sesama santri, guru dengan corak ragamnya, informasi-informasi untuk memasuki pesantren, kontak dengan orangorang sekitar pesantren, program dan suasana pesantren dan menyusun berbagai pengaruh ke arah yang positif bagi perkembangan pendidikan para santri. Figur kiai (pengasuh) dan santri (peserta didik) serta perangkat fisik yang memadai sebuah pesantren senantiasa dikelilingi oleh

28 Irfan Paturohman, "Peran Pendidikan Pondok Pesantren Dalam Perbaikan Kondisi Keberagamaan Di Lingkungnnya", dalam Jurnal Tarbawi, Vol. 1, No. 1 Maret (2012), 65.

${ }_{29}$ Wahyu Nugroho, "Peran Pondok Pesantren Dalam Pembinaan Keberagamaan Remaja",dalam Jurnal Mudarrisa Kajian Pendidikan Islam , Vol. 8, No. 1 Juni-Desember (2016), 90. 
sebuah kultur yang bersifat keagamaan, kultul tersebut mengatur hubungan antara satu masyarakat dengan masyarakat yang lain.

Pesantren dapat juga disebut sebagai lembaga pendidikan luar sekolah, karena eksistensinya berada dalam jalur struktur pendidikan sosial, pesantren memiliki program yang dirangkai sendiri dan pada umumnya bebas dari ketentuan formal, non formal dan informal yang berjalan sepanjang hari dari sistem asrama. Dengan demikian pesantren bukan saja lembaga mencari ilmu, melainkan proses kehidupan itu sendiri. ${ }^{30}$

\section{Apresiasi dan Konsepsi Kepribadian Santri}

Kepribadian berasal dari kata personality (bahasa Inggris) yang berasal dari kata persona (bahasa Latin) yang berarti kedok atau topeng. Yaitu tutup wajah yang sering dipakai oleh pemain-pemain pentas, yang maksudnya untuk melukiskan perilaku, watak, atau pribadi seseorang. Hal itu dilakukan karena terdapat ciri-ciri yang khusus yang hanya dimiliki oleh seseorang tertentu baik dalam arti kepribadian yang baik, ataupun tidak baik. ${ }^{31}$

Menurut Jung (dalam Surbrata, 2003) kepribadian manusia dapat dibedakan menjadi dua, yaitu kepribadian ekstrovert dan kepribadian introvert. Apabila penyesuaian terhadap segala sesuatu yang ditentukan oleh aspek objektif, aspek luar, maka orang yang demikian itu dikatakan memiliki penyesuaian ekstrovert. Sedangkan ada orang yang mempunyai tipe dan penyesuaian introvert, dimana dalam mendapati sesuatu, aspek-aspek yang dominan adalah aspek subjektif yaitu aspek-aspek yang berasal dari dunia jiwa sendiri. ${ }^{32}$

Berhubungan dengan pembentukan kepribadian, terdapat beberapa masalah santri yang menjadi tolak ukur berhasil atau tidaknya bimbingan kepribadian santri. Adapun yang menjadi keberhasilan pembinaan kepribadian santri adalah pola sikap yang ada di pesantren tergurus oleh kondisi dan situasi, perubahan pada sikap terjadi karena pola pikir santri yang berubah semula salafiyah menjadi modern sebagai akibat dari kebedaraan pendidikan formal, meskipun sebenarnya manfaat dari pendidikan formal sangat besar terhadap kemajuan manusia. Tetapi tidak menutup kemungkinan bahwa pendidikan formal membawa dampak terhadap kepribadian santri yang tidak selamanya dampak tersebut positif, ada beberapa fakta di lapangan bahwa kepribadian santri salaf dengan kepribadian santri modern berbeda. ${ }^{33}$

Secara umum, kepribadian dapat diartikan sebagai keseluruhan kualitas perilaku individu yang merupakan cirri khas dalam berinteraksi dengan lingkungannya. Jadi kepribadian santri adalah

\footnotetext{
${ }^{30}$ Jamal

31 Agus Sujanto, Psikologi Kepribadian (Semarang: Bumi Akasara, 2006).

32 Wahyu Rahmat, "Pengarub Tipe Kepribadian Dan Kualitas Persababatan Dengan Kepercayaan Pada Remaja Akhir", dalam Jurnal eJournal Psikologi, Vol. 2, No. 2 (2014), 208.

33 Jamal. 
sifat khas dari diri seorang santri yang bersumber dari lingkungan, yang akan berpengaruh terhadap akhlak, moral, budi pekerti, dan etika santri tersebut.

Menurut Mahmud (1990) kepribadian itu memiliki arti yang lebih dari pada hanya sekedar sifat memukau yang tertata dari semua sifat yang dimilikinya. Sifat tersebut bermacam-macam. Seperti yang berkenaan dengan cara orang berbuat, berhubungan dengan minat, melukiskan sikap, dan temperamen emosionil. ${ }^{34}$

Santri adalah mereka yang dengan taat melaksanakan perintah agamanya, yaitu Islam. Sedangkan asal usul perkataan santri setidaknya ada 2 pendapat yang dapat bisa dijadikan rujukan. Pertama, dari kata "Santri" dari bahasa sansekerta yang artinya melek huruf. Kedua, kata santri yang berasal dari bahasa jawa "Cantrik" yang berarti seseorang yang mengikuti seorang ustad kemanapun pergi atau menetap dengan tujuan dapat belajar suatu keilmuan kepadanya.

Pengertian ini senada dengan pengertian santri secara umum, yakni orang yang belajar agama Islam disebuah pesantren yang menjadi tempat belajar bagi santri. Jika dirunut dengan adat pesantren, terdapat dua kelompok santri, yakni: Santri kalong adalah peserta didik yang berada disekitar pesantren yang ingin menumpang belajar dipesantren pada waktu-waktu tertentu tanpa tinggal atau menginap di asrama pesantren. santri mukim yakni murid-murid yang berasal dari daerah jauh dan menetap dipesantren biasanya menjadi kelompok tersendiri dan sudah memikul tanggung jawab mengurusi kepentingan pesantren sehari-hari, seperti halnya mengajar santrisantri muda tentang kitab-kitab tingkatan rendah dan menengah. ${ }^{35}$

Santri adalah sebutan orang-orang atau anak-anak yang sedang belajar menuntut ilmu di setiap pondok pesantren. Santri tersebut datang dari daerah yang jauh namun ada juga yang tidak jauh rumahnya dari pondok pesantren. Dan santri tersebut ada yang bermuqim dipondok pesantren dan ada juga santri yang tidak bermuqim di pondok pesantren tetapi hanya datang saat belajar saja tetapi setelah selesai belajar langsug pulang kerumahnya masing-masing hal itu dikarenakan rumah santri tersebut dengan pondok pesantren tidak jauh. ${ }^{36}$

Di dunia pesantren biasa juga dilakukan, seorang santri pindah dari suatu pesantren ke pesantren lain. Setelah seorang santri merasa sudah cukup lama di sauatu pesantren, maka dia pindah ke pesantren lain. Biasanya kepindahannya itu untuk menambah dan mendalami suatu ilmu yang menjadi keahlian dari seorang kyai yang didatanginya itu. ${ }^{37}$

\footnotetext{
34 Tohirin, Psikologi Pembelajaran Pendidikan Agama Islam (Jakarta: PT Raja Grafindo Persada, 2005).

35 Mansur Hidayat, "Model Komunikasi Kyai Dengan Santri Di Pesantren", dalam Jurnal Komunikasi ASPIKOM, Vol. 2, No. 6 Januari (2016), 387.

36 Nuryanto, "Eksistensi Pendidikan Pondok Pesantren Terbadap Perubahan Akblak Santri", dalam Jurnal Tarbawiyah, Vol. 10, No. 2 Juli-Desember (2013), 67.

${ }_{37}$ Zulhimma, "Dinamika Perkembangan Pondok Pesantren Di Indonesia", dalam Jurnal Darul 'Ilmi, Vol. 1, No. 2 (2013), 171.
} 


\section{Upaya Pondok Pesantren Pembentukan Kepribadian Santri}

Seperti kita ketahui sistem pendidikan pondok pesantren dibanggakan sebagai yang tidak terpaku pada penimbunan pengetahuan dan pengasahan otak belaka, tetapi juga mementingkan pembinaan kepribadian, karakter manusia dan tingkah laku. Dalam melatih etika, Skinner menjelaskan bahwa istilah shaping, yaitu upaya secara bertahap untuk membentuk tingkah laku, mulai bentuk yang paling sederhana sampai bentuk yang paling kompleks. oleh karena itu pondok pesantren merupakan lembaga pendidikan yang berorientasi pada agama, maka nilai-niali etika (akhlak) yang dijadikan pegangan adalah bersumber dari falsafah keagamaan yang harus diikuti oleh mereka yang terproses di dalamnya secara menyeluruh tanpa syarat. Adapun dalam membina kepribadian santri yang berlangsung di pondok pesantren secara garis besarnya adalah: (1)Penanaman nilai-nilai, Pembinaan dengan pengajaran kitab-kitab akhlak Dalam penanaman nilai-nilai akhlak dengan pengajaran kita-kitab, secara tradisional sistem pendidikan yang diterapkan di pesantren, memilahkan secara tegas aspek pengembangan intelektual dan aspek pembinaan kepribadian. Untuk membina kepribadian anak didik (santri), di pondok pesantren memakai kitab-kitab akhlak seperti Akblakul Banat, Akblakul Banin dan Kitab tafsir Qur'an yang menafsirkan beberapa ayat Al-Qur'an dan hadits yang berkitan dengan budi pekerti dan kewajibankewajiban seorang Muslim. (2) Membiasakan Hidup Berakhlak, Tingkah laku yang menyimpang terdapat pada individu sebagai hasil pengalaman pengondisian yang keliru (faulty of conditioning). Karena itu tugas pertama dari seseorang adalah menghapus tingkah laku yang menyimpang, dan membentuk tingkah laku baru yang layak melalui pemerkuatan atas tingkah laku yang layak itu.

Sikap jiwa agama yang bersungguh-sungguh, jauh dari olok-olokan dan kekesalan. Jika seseorang menderita cobaan atau musibah, ia tidak akan mengeluh karena di samping penderitaan itu, ia mempunyai jalan untuk terlepas dari pada kesukaran tersebut. Sebaliknya kalau gembira dan mendapat keuntungan, maka dia tidak akan melonjak-lonjak kegembiraan, atau tertawa-tawa. ${ }^{38}$

Pembentukkan kepribadian pada dasarnya adalah upaya untuk mengubah sikap-sikap kearah kecenderungan terhadap nilai-nilai keislaman. Dan pembentukkan kepribadian itu sendiri berlangsung secara bertahap, tidak sekali jadi, melainkan sesuatu yang berkembang. Oleh karena itu pembentukkan kepribadian itu sendiri merupakan proses. ${ }^{39}$

${ }^{38}$ Koswara. Teori-Teori Kepribadian. (Bandung: Eresco, 1991).

${ }^{39}$ Ramayulis, Ilmu Pendidikean Islam (Jakarta: Kalam Mulia, 2002). 
Idealisasi out put santri menjadi seorang yang „alim shalih seperti ini kemudian diterjemahkan dalam penempatan cara hidup, nilai, dan prinsip hidup sehari-hari dipesantren. Nilai-nilai tersebut membentuk perilaku santri yang kemudian membangunkan nilai-nilai mereka berada dalam sebuah subtradisi di pesantren, seperti keikhlasan, kesederhanaan, kemandirian, dan keteladanan yang telah sangat lama dipraktikkan di pesantren dan menjadi ciri khas. Seorang Kiai, misalnya, harus rela membuka pintu rumahnya 24 jam untuk melakukan fungsi pelayanan masyarakat. Ini contoh konkrit dari prinsip keikhlasan yang diteladankan kepada para santrinya. Sikap hidup tanpa pamrih atau dalam bahasa pesantrennya "illabi ta" ald" ini menjadikan pesantren mampu bertahan hidup sampai berabad-abad lamanya. Secara lebih luas, ikhlas dalam menuntut ilmu juga dapat diartikan sebagai kesungguhan dan keseriusan dalam belajar. Selama belajar itu santri mengesampingkan kegiatan-kegiatan yang tidak relevan dan bahkan kesenangan sesuai selera pribadinya. Sikap hidup ini lebih menekankan pada proses dari pada hasil. Implikasinya adalah para santri menjadi individu yang tangguh, berjiwa besar, dan tidak takut menghadapi kenyataan pahit dalam hidupnya. Prinsip ikhlas ini juga ditopang dengan prinsip kesederhanaan. Pola hidup sederhana terlihat mulai dari cara santri berpakaian, menyediakan makanan dan minuman sederhana. Sederhana tidak berarti kekurangan, namun sikap hidup sederhana yaitu tidak berlebihan, meskipun halal. Prinsip hidup sederhana ini juga tampak pada nilai yang dikembangkan, yaitu selalu hidup sabar, tawakkal, zubud dan wira"i.

Kepribadian santri yang kokoh harus terus diperkuat dengan berbagai strategi yang handal. Hal ini penting untuk membentengi pengaruh budaya dari luar, agar para santri memiliki kepribadian yang tangguh dalam mewujudkan kehidupan mendatang yang selamat dan sejahtera. Untuk membentuk kepribadian santri yang kuat diperlukan model pendidikan yang dapat dijamin keberhasilannya. Salah satunya adalah model pendidikan yang integrative. Namun bagaimana secara operasional model pendidikan integrative ini membentuk kepribadian santri.

Secara umum kepribadian seseorang terbentuk karena dipengaruhi oleh dua hal: (1) Fitrah bawaan sejak lahir dari warisan genetika orang tuanya. Juika orang tuanya berakhlaq baik maka anaknya akan berakhlaq baik, jika orang tuanya memiliki sifat-sifat yang buruk, maka sifat-sifat tersebut akan terdapat pula pada anaknya, sehingga terbentuklah kepribadian. (2) Melalui proses panjang riwayat hidupnya. Proses internalisasi nilai pengetahuan dan pengalaman dalam dirinya. Dalam pandangan ini maka keyakinan agama yang ia dapatkan dari pengetahuan maupun dari pengalaman masuk dalam struktur kepribadian seseorang. Anak yang dibina dengan nilai-nilai keislaman akan terbiasa menjalankan ibadah, patuh pada kewajiban-kewajiban seorang muslim. ${ }^{40}$

${ }^{40}$ Badrus Abd Qadir, "Membangun Kepribadian Santri Melalui Integrasi Pendidikan Di Pesantren Terpadu Daru Ulil Albab Kelutan Ngronggot Nganjuk", dalam Jurnal Pendidikan Islam, Vol. 7, No. 1 Mei (2017), 1. 
Kemudian Abu Usaid menjelaskan bahwa kepribadian manusia itu terbentuk dari pola pikir ('aqliyah) dan pola jiwa (nafsiyab) nya. (1) Pola pikir, Pola pikir manusia terkait dengan bagaimana ia memahami sesuatu melalui upayanya mengaitkan berbagai informasi yang diterimanya dengan fakta-fakta yang ada atau sebaliknya, yang kemudian disandarkan pada satu atau beberapa prinsip (pandangan hidup) tertentu. Sebagaimana dijelaskan diatas bahwa pembentukkan itu merupakan proses. ${ }^{41}$ (2) Pola jiwa, Pola jiwa (nafsiyab) terkait dengan bagaimana cara seseorang memenuhi kebutuhan jasmaniyah dan naluriyah (al Hajah al 'udhawiyah wa al gharaiz). Cara pemenuhan kebutuhan dari kedua aspek ini akan nampak ketika seseorang berusaha mengaitkan berbagai dorongan kebutuhannya dengan pemahaman yang ada pada dirinya. Proses pengaitan dorongan kebutuhan dengan pemahaman ini akan melahirkan kecenderungan (muyul) atau apa yang disebut dengan pola jiwa ini. ${ }^{42}$

\section{Kesimpulan}

Dari uraian diatas, bisa diambil kesimpulan bahwa cara membentuk kepribadian santri terutama membentuk kepribadian santri ialah:

1. Penanaman nilai-nilai, dimana pembinaan dengan pengajaran kitab-kitab. Untuk membina kepribadian anak didik (santri), di pondok pesantren memakai kitab-kitab akhlak seperti Akblakul Banat, Akblakul Banin dan Kitab tafsir Qur'an yang menafsirkan beberapa ayat AlQur'an dan hadits yang berkitan dengan budi pekerti dan kewajibankewajiban seorang Muslim.

2. Membiasakan dengan hidup beretika (berakhlak), Tingkah laku yang menyimpang terdapat pada individu sebagai hasil pengalaman pengondisian yang keliru (faulty of conditioning). Karena itu tugas pertama dari seseorang adalah menghapus tingkah laku yang menyimpang, dan membentuk tingkah laku baru yang layak melalui pemerkuatan atas tingkah laku yang layak itu.

\section{Daftar Pustaka}

Arifin, Muzayyin, 2003, Kapita Selekta Pendidikan Islam, Jakarta: Bumi Aksara.

Atabik, "Historisitas Dan Peran Pondok Pesantren Somalangu Di Pesisir Selatan", dalam Jurnal Ibda' Kebudayaan Islam, Vol. 1, No. 2 Juli-Desember (2014).

Azra, Azyumardi, 2000, Pendidikan Islam: Tradisi dan Modernisasi di Tengah Tantangan Milenium III, Jakarta: Logos Wacana Ilmu. 2011).

41 Abdul Majid, Dian Andayani, Pendidikan Karakter Perspektif Islam (Bandung: PT Remaja Rosdakarya, 42 Jamal. 
Baharun, Hasan, 2017, Pengembangan Kurikulum : Teori Dan Praktik, Yogyakarta: Pustaka Nurja.

Baharun, Hasan and Robiatul Awwaliyah, "Pendidikan Multikultural Dalam Menanggulangi Narasi Islamisme Di Indonesia", Jurnal Pendidikan Agama Islam (Journal of Islamic Education Studies), Vol. 5, No. 2 (2017).

Baharun, Hasan, "Peningkatan Kompetensi Guru Melalui Kepemimpinan Kepala Madrasab", dalam Jurnal At-Tajdid: Ilmu Tarbiyah, Vol. 6, No. 1 Juli (2017).

Baharun, Hasan, "Total Moral Quality: A New Approach for Character Education in Pesantren", dalam Jurnal Ulumuna, Vol. 21, No. 1 June (2017).

Fajar, M. 1998, Visi Pembaruan Pendidikan Islam, Jakarta: Lembaga Pengembangan Pendidikan dan Penyusunan Naskah Indonesia.

Fauzan, 2008, Sejarah Sosial Pendidikan Islam, Jakarta: Kencana.

Haidar, Dauly, 2001, Historisitas dan Eksistensi Pesantren, Sekolah dan Madrasah, Yogyakarta: Tiara Wacana.

Hasyim, Husmiaty, "Transformasi Pendidikan Islam (Konteks Pendidikan Pondok Pesantren)", dalam Jurnal Ta'lim Pendidikan Islam, Vol. 13, No. 1 (2015).

Heriyudanta, Muhammad, "Modernisasi Pendidikan Pesantren Perspektif Azyumardi Ažra", dalam Jurnal Mudarrisa Kajian Pendidikan Islam, Vol. 8, No. 1 Juni (2016).

Hidayat, Mansur, "Model Komunikasi Kyai Dengan Santri Di Pesantren", dalam Jurnal Komunikasi ASPIKOM, Vol. 2, No. 6 Januari (2016).

Jamal, Nur, "Transformasi Pendidikan Pesantren Dalam Pembentukan Kepribadian Santri", dalam Jurnal Tarbiyatuna: Pendidikan Islam, Vol. 8, No. 2Agustus (2015).

Koswara. 1991, Teori-Teori Kepribadian, Bandung: Eresco.

Manfred, Ziemek, 1986, Pesantren Dalam Perubahan Sosial, Jakarta: P3M.

Muhakamurrohman, Ahmad, "Pesantren: Santri, Kiai, Dan Tradisi", dalam Jurnal Ibda' Kebudayaan Islam, Vol. 12, No. 2 Juli-Desember (2014).

Mukromin, "Implementasi Pendidikan Karakter Di Pesantren", dalam Jurnal Al-Qalam, Vol. XII.

Mumtahanah, Nurotun, "Pengembangan Sistem Pendidikan Pesantren dalam Meningkatkan Profesionalisme Santri” AL HIKMAH Jurnal Studi Keislaman, Vol. 5, No. 1 Maret (2015).

Mustofa, Syaiful, "Pendidikan Islam Dalam Perspektif Pesantren (Antara Idealita DAN Realita Di Era Modern)", dalam Jurnal El-Hikmah Fakultas Tarbiyah UIN Maliki Malang.

Nata, Abuddin, 2012, Sejarah Sosial Intelektual Islam, Jakarta: Rajawali Pers.

Nofiaturrahmah, Fifi, "Metode Pendidikan Karakter Di Pesantren", dalam Jurnal Pendidikan Agama Islam, Vol. XI, No. 2 Juni-Desember (2014). 
Nugroho, Wahyu, "Peran Pondok Pesantren Dalam Pembinaan Keberagamaan Remaja",dalam Jurnal Mudarrisa Kajian Pendidikan Islam, Vol. 8, No. 1 Juni-Desember (2016).

Nuryanto, "Eksistensi Pendidikan Pondok Pesantren Terbadap Perubahan Akblak Santri", dalam Jurnal Tarbawiyah, Vol. 10, No. 2 Juli-Desember (2013).

Paturohman, Irfan, "Peran Pendidikan Pondok Pesantren Dalam Perbaikan Kondisi Keberagamaan Di Lingkungnnya", dalam Jurnal Tarbawi, Vol. 1, No. 1 Maret (2012).

Prasodjo, Sudjoko, 2001, Sejarah Pertumbuhan dan Perkembangan Lembaga-lembaga Pendidikan Islam di Indonesia, Jakarta: Grasindo.

Qadir, Badrus Abd, "Membangun Kepribadian Santri Melalui Integrasi Pendidikan Di Pesantren Terpadu Daru Ulil Albab Kelutan Ngronggot Nganjuk", dalam Jurnal Pendidikan Islam, Vol. 7, No. 1 Mei (2017).

Qomar, Mujamil, 2002, Pesantren Dari Transformasi Metodologi Menuju Demokrasi Institusi, Jakarta: Erlangga.

Rahmat, Wahyu, "Pengarub Tipe Kepribadian Dan Kualitas Persababatan Dengan Kepercayaan Pada Remaja Akhir", dalam Jurnal eJournal Psikologi, Vol. 2, No. 2 (2014).

Ramayulis, 2002, Ilmu Pendidikan Islam, Jakarta: Kalam Mulia.

Rizal, Ahmad Syamsu, "Pesantren Corak Edukasi Dalam Sistem Pendidikan Pesantren, Dari Pola Tradisi Ke Pola Modern", dalam Jurnal Urnal Pendidikan Agama Islam -Ta'lim, Vol. 9, No. 2 (2011).

Saridjo, Marwan, 1982, Sejarah Pondok Pesantren di Indonesia, Jakarta: Darmabhakti.

Setyaningsih, Rini, "Kontinuitas Pesantren Dan Madrasah Di Indonesia", dalam Jurnal At-Ta'dib, Vol. 11, No. 1 Juni (2016).

Sujanto, Agus, 2006, Psikologi Kepribadian, Semarang: Bumi Akasara.

Tanshzil, Sri Wahyuni, "Model Pembinaan Pendidikan Karakter Pada Lingkungan Pondok Pesantren Dalam Membangun Kemandirian Dan Disiplin Santri", dalam Jurnal Penelitian Pendidikan, Vol. 13, No .2 Oktober (2012).

Tohirin, 2005, Psikologi Pembelajaran Pendidikan Agama Islam, Jakarta: PT Raja Grafindo Persada. Zuhriy, M. Syaifuddien, "Budaya Pesantren Dan Pendidikan Karakter Pada Pondok Pesantren Salaf", dalam Jurnal Walisongo; Penelitian Sosial Keagamaan, Vol. 19, No. 2 November-Desember (2011).

Zulhimma, "Dinamika Perkembangan Pondok Pesantren Di Indonesia", dalam Jurnal Darul 'Imi, Vol. 1, No. 2 (2013) 